\title{
Doctrine of State Continuity. Latvia's Experience
}

\author{
Dr. iur. Ineta Ziemele \\ Professor of International Law at Riga Graduate School of Law \\ Judge at the Court of Justice of the European Union \\ former President of the Constitutional Court of the Republic of Latvia \\ former Judge and President of Section of the European Court of Human Rights \\ E-mail: ineta.ziemele@curia.europa.eu
}

\section{Dr. hist. Ainārs Lerhis}

Senior Researcher at the Institute of Latvian History, University of Latvia Senior Researcher at the Centre for East European Policy Studies (Riga)

E-mail:ainars_lerhis@yahoo.co.uk

\author{
Dr. iur. Jānis Pleps \\ Faculty of Law, University of Latvia \\ Assistant Professor at the Department of Legal Theory and History \\ E-mail:janis.pleps@lu.Iv \\ Dr. iur. Jānis Lazdiṇš \\ Faculty of Law, University of Latvia \\ Professor at the Department of Legal Theory and History \\ E-mail: Janis.Lazdins@lu.Iv
}

\begin{abstract}
The article examines the scope and consequences the continuity of the Republic of Latvia in several domains and places them within a broader context of Latvia's history. Firstly, it describes and analyses some functions of the State of Latvia which continued to be performed during the years of occupation by the USSR and Nazi Germany (1940-1990) and, secondly, the significance of the de iure effect of the Satversme of the Republic of Latvia of 15 February 1922 during the years of occupation and following the restoration of the independence of the state. The authors advance the thesis that the occupation regimes of the communist USSR and Nazi Germany failed to extinguish the existence of the Republic of Latvia as an internationally recognised subject of international law, moreover, Latvia in practice did not discontinue performing some functions of the state. Of course, full restoration of the independence of the state on the basis of values enshrined in the Satversme occurred only after coup d'état in the Soviet Union.
\end{abstract}

Keywords: foreign (diplomatic and consular) service, Satversme (Constitution of Latvia), state continuity, restoration of independence, denationalisation, property. 


\section{Contents}

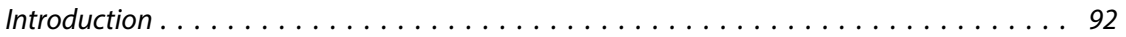

1. Implementing of Foreign Affairs Functions of Latvian State During Occupation . . . . . 93

1.1. Changes in Latvian Foreign Service Stemming from Loss of Independence

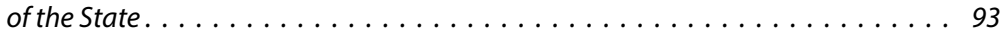

1.2. Main Activities During the Second World War

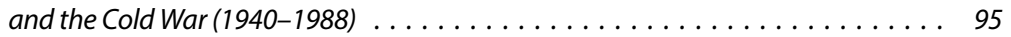

1.3. Main Activities During the Years of Third Awakening Until Full Restoration

of the Independence of Latvian State (1988-1991) . . . . . . . . . . . . . . . 98

2. Full Restoration of Sovereign State Power . . . . . . . . . . . . . . . . . . . . . . . 99

2.1. Validity of Satversme During Occupation . . . . . . . . . . . . . . . . . . . 99

2.2. Reinstatement of Satversme and Restoration of Constitutional Bodies

Defined Therein . . . . . . . . . . . . . . . . . . . . . . . . . . . 100

2.3. Restitution of the Right to Property. . . . . . . . . . . . . . . . . . 102

Summary. . . . . . . . . . . . . . . . . . . . . . . . . . . 106

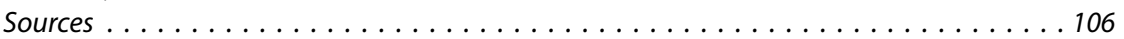

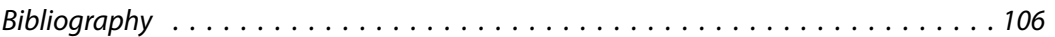

Normative Acts . . . . . . . . . . . . . . . . . . . . . . . 108

Constitutional Laws. . . . . . . . . . . . . . . . . . . . . . . . . 108

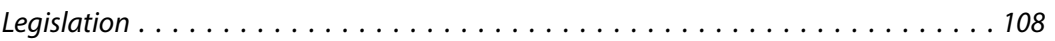

Case Law...................................... 109

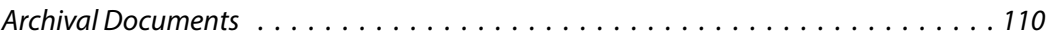

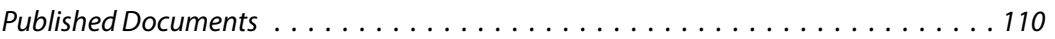

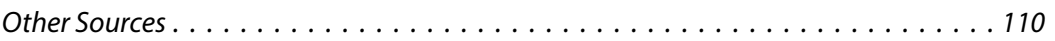

\section{Introduction}

On 18 November 1918, Latvia was promulgated as an independent, democratic republic. On 15-17 June 1940, the Republic of Latvia was occupied by the USSR. During the Second World War, the Soviet occupation was replaced by the occupation by Nazi Germany (1941-1945). The communist regime was restored after the war. The Soviet occupation power in Latvia, although unlawful, endured for almost half a century. The Republic of Latvia continued to exist de iure as an internationally recognised subject of international law for the entire period of occupation. De facto the independent State of Latvia was restored in 1990-1991. Following the restoration of Latvia's sovereign power on the territory of the state, the legal and practical questions stemming from state continuity emerged, and the doctrine or principle of state continuity gained prominence amongst the research themes in scholarly writings.

A group of researchers, consisting of historians, political scientists and lawyers, was established to study the doctrine of state continuity in the context of Latvian history. Noteworthy scientific material was collected in the framework of cooperation project of fundamental and applied research No. 653/2014 "Experience, lessons learned and international significance of restoring the independent statehood of Latvia (historical, political and legal aspects)". All the issues analysed in the project have not been addressed in this article. ${ }^{1}$ The current article introduces the international research community (in particular, the lawyers belonging to it)

1 The research results of the project have been published in a book: Nepārtrauktības doktrina Latvijas vēstures kontekstā [The Continuity Doctrine in the Context of Latvia's History]. Collective of authors, research supervisor Jundzis, T. Rỉga: Latvijas Zinātṇu akadēmijas Baltijas stratēgisko pētījumu centrs, 2017. Another more extensive article stemming from this research and focusing on the findings in 
with two aspects of the research, which until now have been little discussed on an international level.

The first aspect is related to the functioning of Latvia's foreign service during the years when the State of Latvia was occupied by the USSR and Germany, the second - to the significance of the Satversme of the Republic of Latvia during the years of communist and Nazi occupations. In relation to the second issue, it should be taken into account that an anti-constitutional coup d'état took place on 15 May 1934. The functioning of Kārlis Ulmanis' government until the additional contingent of the Red Army was moved into the territory of Latvia (16-17.06.1940) was incompatible with the values enshrined in the Satversme. However, the undemocratic government of the state did not undermine the existence of the State of Latvia either de iure or de facto.

The authors set the following aim for this article - to analyse the significance of the functioning of Latvia's foreign service and of the Satversme during the years of Latvia's occupation and during the period leading to the full restoration of the sovereign state power for the purposes of state continuity thesis of Latvia.

\section{Implementing of Foreign Affairs Functions of Latvian State During Occupation}

\subsection{Changes in Latvian Foreign Service Stemming from Loss of Independence of the State}

The fact that the foreign services of the three Baltic states - Latvia, Lithuania and Estonia - continued their operations in the Western countries in 1940-1991 attested de iure existence of these states. The Latvian foreign service (diplomatic and consular service) in the Western states after the Baltic states were occupied by the USSR in 1940 was an institution of the state power of the Republic of Latvia, which continued performing functions of the state power since the representations were located outside the territory of occupied Latvia. The service continued its work uninterruptedly throughout the whole period of Latvia's occupation until the restoration of the state's independence in 1991. This possibility was ensured by the non-recognition of the occupation of Latvia by many states.

A month prior to Latvia's occupation, on 17 May 1940, the government of Latvia granted Kārlis Zariņš (Charles Zarine), the Envoy to Great Britain, extraordinary powers to defend Latvia's interests in almost all countries. These powers would enter into effect also in case if the government were to be unable to maintain connections with Latvia's diplomatic and consular missions. ${ }^{2}$ These powers were intended to enable continuing representation of the interests of the Latvian state abroad in an emergency, in conditions of war. Although the extraordinary powers had significant deficiencies and were limited, in the future they would play an important role in the

international law is included in volume 19, 2020, of the Baltic Yearbook of International Law published by the Riga Graduate School of Law and the Brill Publishers.

2 Latvian National Archives, Latvian State Historical Archive (hereafter - LNA LSHA), 293. fonds [fund] (hereafter - f.), 1. apraksts [description] (hereafter - apr.)., 4388. lieta [file] (hereafter - 1.), pp. 12, 16, 17, 28; Hoover Institution Archives, Vilis Sumans collection, box 1, folder "Increment April 1978"; Latvijas Republikas oficiālā nostāja Latvijas diplomātiskā dienesta dokumentos 1940.-1991. gadā. Dokumentu krājums [The Official Position of the Republic of Latvia in the Documents of the Latvian Diplomatic Service in 1940-1991. Collection of Documents]. Compiled by Lerhis, A. Rìga: Latvijas vēstures institūta apgāds, 2015, pp. 41-42. 
fight for continuity of de iure existence of the Latvian state and ensuring the further operations of the Latvian diplomatic and consular service.

The Latvian government decided to accept the ultimatum advanced by the USSR on 16 June 1940 and did not resist the occupation of Latvia realized by the USSR (17 June) either through a diplomatic protest or in a military way, ${ }^{3}$ it also did not forward any instructions for setting into motion the extraordinary powers. ${ }^{4}$ In midJuly, before the declaration by the Latvian "People's" Saeima on the establishment of the Soviet power (21 July) and incorporation of Latvia into the Soviet Union (5 August), the diplomatic representatives of the last independent government of the Republic of Latvia, accredited in several Western states, commenced diplomatic fight against this aggression by the USSR. The employees of the Latvian diplomatic service abroad assessed this situation as a fact of occupation, ${ }^{5}$ several envoys took a very strong stance against annihilation of Latvia's independence. In these diplomatic protests, they invited the governments of their countries of residence (the United States, Great Britain, etc.) to not recognise Latvia's occupation by the USSR.

The bearer of the extraordinary powers of the government of the Republic of Latvia, the head of the foreign services and Envoy to Great Britain K. Zariņs and the deputy of the bearer of the extraordinary powers, the Envoy to the United States Alfrēds Bìlmanis and other envoys prepared and expressed the official opinion of the Latvian state on matters of international policy pertaining to the interests of the State of Latvia and its citizens. ${ }^{6}$ The basic principles of the state's position were elaborated (political and legal positions), which the foreign service followed throughout the next 50 years until the independence of the state was regained.

The Latvian foreign service continued to operate abroad on a significantly reduced scale without the support of an independent government and the Ministry of Foreign Affairs. The main objective of the service was to continue representing the State of Latvia, to preserve the state's international law status, to fight for the restoration of independence in the future, as well as to protect Latvia's citizens and their property abroad. Despite numerous restrictions in the international diplomatic environment in comparison to the diplomats representing the heads of independent states and the governments thereof, the Latvian diplomats via diplomatic channels strived to inform other states about Latvia's opinion. There are grounds for considering these activities as a continuation of the foreign policy of the State of Latvia at least in these matters, although in a very limited scope.

3 LNA LSHA, 1307. f., 1. apr., 317. 1., p. 172; Gore, I., Stranga, A. Latvija: neatkarības mijkrēslis. Okupācija. 1939. gada septembris - 1940. gada jūlijs [Latvia: The Twilight of Independence. Occupation. September 1939 - July 1940]. Rìga: Izglitíba, 1992, pp. 115-117.

4 Lùsis, J. Latvijas diplomātu darbs [Work of Latvian Diplomats]. Daugavas Vanagu Mēnešraksts, No. 3, 1990, p. 11.

5 Feldmanis, I., Freimanis, A. A., Lerhis, A., Ziemele, I. Latvijas valsts okupācijas gados [The Latvian State in the Years of Occupation]. In: Dokumenti par Latvijas valsts starptautisko atzǐšanu, neatkaribas atjaunošanu un diplomātiskajiem sakariem 1918-1998 [Documents on the International Recognition, Restoration of Independence and Diplomatic Relations of the State of Latvia in 1918-1998]. Riga: Nordik, 1999, p. 132; Lerhis, A. Pārmaiṇas Latvijas diplomātiskā dienesta darbībā (1940. g. jūnijs 1942. g. augusts) [Changes in the Operations of the Latvian Diplomatic Service (June 1940 - August 1942)]. In: Vēsturnieks profesors Dr. phil., LZA ārzemju loceklis Andrievs Ezergailis: Biobibliogrāfija, darbabiedru veltijumi 70 gadu jubilejā [Historian Professor Dr. phil., LAS Foreign Member Andrievs Ezergailis: Biobibliography, Dedications of Colleagues on the $70^{\text {th }}$ Anniversary], Riga: Latvijas vēstures institūta apgāds, 2000, p. 169.

6 Feldmanis, I., Freimanis, A. A., Lerhis, A., Ziemele, I. Latvijas valsts okupācijas gados [The Latvian State in the Years of Occupation], p. 132; Lerhis, A. Pārmainas ... [Changes ...], p. 180. 
The Statement by the US Acting Secretary of State Sumner Welles on 23 July 1940 ensured that the diplomatic representations of the Baltic states continued their activities in the USA. ${ }^{7}$ The stance taken by Latvia's diplomatic representatives also facilitated the fact that the USA and Great Britain in the summer of 1940, later followed by other Western states applied the principle of non-recognition of violent conquests also to the Baltic states and commenced de iure non-recognition of the occupation of the Baltic states. ${ }^{8}$

\subsection{Main Activities During the Second World War and the Cold War (1940-1988)}

The diplomatic and consular representations of the Republic of Latvia continued operations in several states: the entire period of Latvia's occupation - legations in Washington and London, for a shorter term - legations in Buenos Aires (1940-1946), in Geneva (1940-1946), in Rio de Janeiro (1944-1961), diplomatic representations in Madrid (1953-1959) as well as, in various periods, - numerous career consuls and honorary consuls. ${ }^{9}$

In 1940-1991, the work of Latvia's representations abroad was managed by the heads of the Latvian diplomatic and consular service: Kārlis Zariņš (1940-1963), Arnolds Spekke (1963-1970; thus, the service's centre of command moved from the legation in London to the legation in Washington) and Anatols Dinbergs (1971-1991). They set the guidelines on foreign policy matters and appointed the employees of the representations, consuls and personal representatives. In the future, the activities were determined by the head of the Latvian diplomatic and consular service and the head of the respective representations.

As recognised by the Constitutional Court of the Republic of Latvia in May 2010, during the period of occupation, the activities of Latvia's diplomatic representations were the sole manifestation of the capacity of the Latvian state, and, in the extraordinary situation caused by the occupation (absence of the government's support), this limited capacity of the state also determined the activities of the representations. For the further 50 years, the Latvian diplomats abroad maintained the claim regarding the State of Latvia, and this fact is significant in the context of the doctrine on the state's continuity. ${ }^{10}$

7 Statement of Acting Secretary of State Sumner Welles, July 23, 1940. In: U.S. Department of State, Department of State Bulletin III. Washington, U.S. Government Printing Office, July 27, 1940. Vol. III, No. 57, p. 48; Rietumvalstu nostāja Baltijas valstu jautājumā 1940.-1991. gadā: Dokumentu krājums [Position of the Western Countries on the Issue of Baltic States in 1940-1991. Collection of Documents]. Compiled by Lerhis, A. Rīga: Latvijas vēstures institūta apgāds, 2018, pp. 66-67; Sūtniecība Vašingtonā [Legation in Washington]. In: Latvju Enciklopēdija [Latvian Encyclopaedia]. Ed. Andersons, E. Vol. 4. Rockville, 1990, p. 510.

8 Feldmanis, I., Freimanis, A. A., Lerhis, A., Ziemele, I. Latvijas valsts okupācijas gados [The Latvian State in the Years of Occupation], pp. 134-135.

9 [Lerhis, A.]. Ieskats Latvijas Republikas ārlietu dienesta vēsturē (1917-1997) [Insight into the History of the Foreign Service of the Republic of Latvia (1917-1997)]. In: Latvijas ārlietu dienesta rokasgrāmata [Handbook of Foreign Service of Latvia]. Rīga: Latvijas Republikas Ārlietu ministrija, 1997, p. 17.

10 Latvijas Republikas Satversmes tiesas 2010. gada 13. maija spriedums lietā Nr. 2009-94-01 [Judgement by the Constitutional Court of the Republic of Latvia of 13 May 2010 in Case] No. 2009-94-01. Available: http://www.satv.tiesa.gov.lv/upload/spriedums_2009_94_01.htm [last viewed 12.12.2015]; Address of President of Latvia, Egils Levits, at the reception marking 100 years of foreign service (09.09.2019). Available: https://www.president.lv/en/news/news/address-of-president-of-latviaegils-levits-at-the-reception-marking-100-years-of-foreign-service-25901\#gsc.tab=0 [last viewed 02.04.2021]. 
In Latvian legations, the political work mainly focused on activities of informative nature and fight for Latvia's existence and rights. The work with Latvia's citizens, vessels, etc. was mainly concentrated in the consular branch and was recognised as being very important. ${ }^{11}$ The legation in Washington assumed the consular oversight over Latvian vessels and seamen, as well as the protection of the owners' interests. During the period of Latvia's occupation, the state's diplomatic and consular representations in the Western countries in their activities followed the legal acts of the pre-occupation period. They remained in force also after Latvia's occupation. Furthermore, during the following 50 years, the diplomats of Latvia's foreign service continued to declare their subordination to the last sovereign Latvian government of the pre-war period, which was internationally recognised.

The beginning of the Soviet-German war (on 22 June 1941) and replacement of the Soviet occupation by the German occupation did not interrupt de iure existence of the Republic of Latvia and its right to be a free, sovereign and independent state. Similarly to the envoys' actions in 1940, declaring the position against the Soviet occupation, in 1941 they also protested against the occupation of Latvia by Nazi Germany, appealing to the governments of their countries of residence.

The diplomats' duty was to speak on behalf of the citizens of Latvia who had gone abroad, and also of those living in the conditions of the Nazi and the Soviet regimes (in Latvia, Siberia, etc.). The employees of the Latvian foreign service developed cooperation with the representatives of the Estonian and Lithuanian foreign services. Slightly later, cooperation was established with the Latvian resistance movement, which stood against both foreign powers and fought for restoration of the independence of the Latvian state.

During the war years, the Latvian diplomats regularly reminded of the international law existence and status of the State of Latvia, of the conditions in Latvia and the violations of international law committed by Nazi Germany and the USSR, as well as the crimes against the State of Latvia and its inhabitants, called attention to its right to restoration of independence. K. Zariňš and A. Bīlmanis had to reject and refute both the Soviet and the Nazi propaganda statements.

The serving and former Latvian diplomats in the Western countries greatly contributed to informing the Western democratic states about the situation in Latvia. ${ }^{12}$ Starting with 1942, the envoys drew up and disseminated memoranda on the situation in Latvia, the Nazi occupation, the second Soviet occupation, and the Latvian refugees in the Western countries. Envoy A. Bilmanis was particularly active in this informative work against the Soviet and Nazi propaganda in the West and, during the war years, published several brochures on Latvia's situation - the legal status and the policies of the Nazi and Soviet regimes in Latvia. ${ }^{13}$

The diplomats of the Baltic states operated in the courts of the countries of residence together with attorneys, who defended the interests of the Baltic states.

11 A. Bīlmanis' letter of 07.09.1940 to K. Zarinš; file "1940. D. 125.63/ Latvian Consulate-General, New York". LNA LSHA, Latvian Legation London fund (the archival file has not yet been assigned a file number).

12 File "Sarakste ar Foreign Office lidz 1945. g." [Correspondence with Foreign Office until 1945]. LNA LSHA, Latvian Legation London fund, box No. 460 (the archival file has not yet been assigned a file number).

13 Bilmanis, A. Latvia under German Occupation, 1941-1943. Washington: Press bureau of the Latvian Legation, 1943, Vol. I, 114 p.; 1944, Vol. II, 30 p.; Bilmanis, A. The Baltic States in Postwar Europe. Washington: Press bureau of the Latvian Legation, 1943, 48 p.; Bilmanis, A. Latvia Between the Anvil and the Hammer. Washington: The Latvian Legation, 1945, 64 p.; etc. 
The foreign courts studied the documents submitted by the diplomats, the legal acts of Latvia and took these into account. While the Baltics were occupied by Nazi Germany, there were several legal proceedings before the US courts in connection with the attempts by the Soviet Union to take over the ships of the Baltic states. ${ }^{14}$

From 1940 to 1945, foreign powers replaced one another in Latvia three times. After the end of the Second World War and the beginning of the second Soviet occupation, the activities of the Latvian foreign service in defending the interests of the state and citizens, and supporting the self-organisation of the exile community in the countries of residence was of particular importance, ${ }^{15}$ especially during the initial stage when strong exile political organisations had not yet formed.

Over time, K. Zariņš appointed several diplomatic representatives, promoted several diplomats and consuls or transferred them to other places of service, he also appointed personal representatives. The persons from former diplomatic or consular circles were appointed as career consuls in several countries to which large numbers of Latvian refugees had moved. ${ }^{16}$

For fifty years, the Latvian diplomats abroad tirelessly reminded the world about Latvia's existence and defended its rights, ensured the legal existence of the state, preserved the largest part of Latvian gold abroad, safeguarded the small territories of Latvia's representations in the capitals of the Western states also at the time when, for long years, there was almost no hope of change. Within the limits and traditions of the existing law and legal acts, they defended the rights and interests of the Latvian citizens who had gone abroad. Employees tried to find resources to purchase medicines and support refugees. The diplomatic representatives abroad defended the property issues of the vessels owned by the Republic of Latvia in foreign ports and seamen's interests, property issues of legation's buildings, understood the need to unite the exile Latvians. Significant work was done to settle matters of consular nature, seeking lost relatives and news about Lat vians dispersed in foreign countries, issuing Latvian foreign passports and extending their terms of validity (passports of the Republic of Latvia were recognised by several West European, Latin American, Asian and African states and by Australia), issuing certificates, etc. The USSR repeatedly attempted to force the Western states to close the representations of the Baltic states. Latvian legations published the declarations by the Western states and other documents, insofar as these pertained to Latvia, provided information about the situation in Latvia, obtained from various sources. The legation in Washington published "Latvian Information Bulletin". Latvian representations cooperated with the Latvian and Baltic organisations in the Western states. ${ }^{17}$ Latvian diplomats sometimes were received by the heads of several states and other high-standing officials, representatives of international organisations.

The Latvian legation in the US regularly submitted documents to the US Department of State and the United Nations Organisation, pointing to international law violations against Latvia, requested that the interests of the Latvian state and

14 File "Miscellaneous (War time), mainly Washington". LNA LSHA, Latvian Legation London fund (the archival file has not yet been assigned a file number).

15 Kangeris, K. Latvijas pavalstnieki kara laika Eiropā [Latvian Subjects during the War in Europe]. Mājas Viesis, 19.04.2003, pp. 8-9.

16 [Lerhis, A.]. Ieskats ... [Insight ...], pp. 17-19.

17 Lerhis, A. Neatkarības idejas saglabāšana pēckara gados: Latvijas diplomātiskā dienesta ieguldījums mūsu valsts de iure statusa saglabāšanā (1940.-1988. g.) [Maintaining the Idea of Independence during the Post-War Years: Contribution of the Latvian Diplomatic Service to Maintaining de iure Status of Our State (1940-1988)]. Diena, 13.02.1998, p. 13. 
people would be taken into account in preparing and adopting various decisions by the governments of the Western states and international organisations, in cases of convening international conferences, and also followed that the position of the Western states in the matter of non-recognition of the occupation and incorporation of the Baltic states would not be reviewed.

\subsection{Main Activities During the Years of Third Awakening Until Full Restoration of the Independence of Latvian State (1988-1991)}

At the end of 1988, the Latvian legation in Washington initiated unofficial contacts with the representatives of movements for supporting independence from Latvia. In 1989, the representatives of the Latvian Popular Front (LPF) commenced foreign policy activities. Cooperation between LPF and the Latvian foreign service began. Representatives of the legation in Washington provided assistance in preparing the visits by the LPF's representatives to the US State Department and participated in these themselves. Latvia's diplomatic representatives supported the LPF's course towards regaining the independence.

Following the adoption of "Declaration on the Restoration of Independence of the Republic of Latvia" on 4 May 1990, the re-establishment of the Ministry of Foreign Affairs of the Republic of Latvia began. In 1990-1991, the legation in Washington and the whole Latvian foreign service did not represent the government of Latvia of the transitional period (from 4 May 1990 until 21 August 1991) and was not subjected to the Ministry of Foreign Affairs in Riga. Diplomats did not recognise the Supreme Council as the parliament of independent Latvia and the Council of Ministers as an independent government because the restoration of independence had not been internationally recognised yet. However, already since the summer of 1990, the foreign service unofficially cooperated with the new government and the legation in Washington - with the new Ministry of Foreign Affairs. Measures were implemented to expand the Latvian diplomatic and consular network abroad by the representatives, appointed by the legation in Washington, in several capitals of the Western countries. The legation and the Ministry of Foreign Affairs reached an agreement on coordinating the appointment of honorary consuls. In 1989-1991, the Latvian foreign service in the Western countries attached great importance to the issues of legal continuation of the Latvian state and provided recommendations to the Latvian leaders on these matters.

The constitutional law "On the Statehood of the Republic of Latvia", adopted by the Supreme Council on 21 August 1991, was of decisive importance in restoring the full independence of the State of Latvia. After this date, the foreign policy of the Republic of Latvia and the operations of the Ministry of Foreign Affairs developed in full scope. Those several long-serving Latvian diplomats, who experienced the restoration of the state's independence actually linked both periods of the independence of the Latvian state in person. Just like the diplomatic and consular representations, for many years they were perceived as the symbols of the state's existence.

In brief, maintaining de iure status of Latvia and of the other Baltic states, as well as continuing the work of the three states' foreign services for 50 years, the diplomats' work for many years and faith in restoring the state's independence is an unprecedented case in the history of global diplomacy and international law, which, inter alia, explains the scope of the principle of non-recognition of unlawful actions. The Latvian diplomats acted in compliance with the provisions of international law, 
the legal acts of the Republic of Latvia and the state's international commitments, retained their diplomatic status and the status of the legations, used political and legal arguments in assessing the crimes committed by the occupation powers, explaining the status of the Latvian citizen and constitutional matters of Latvia to the exiles abroad, in analysing the international situation and using the existence of de iure status of the state on the way towards regaining the independent statehood in accordance with the doctrine of the legal continuity of the State of Latvia.

\section{Full Restoration of Sovereign State Power}

\subsection{Validity of Satversme During Occupation}

Although the functioning of the Satversme was suspended after the coup d'état of 15 May 1934, the Satversme, nevertheless, was not revoked. Moreover, during the period of Latvia's occupation, it continued to be in legal force as the only permanent constitution of Latvia. Pursuant to the Satversme and the principles included therein, it was possible to identify the anti-constitutionality of the procedure of sovietisation, "staged" by the USSR, aiming to liquidate the State of Latvia. ${ }^{18}$

The Satversme became the legal basis for the activities of the national resistance movement, when the citizens of Latvia engaged in the fight for regaining the lost independence. References to the violated norms of the Satversme were used to substantiate the illegality of the actions by the USSR; likewise, the attempts to restore the independence of the state were based on the Satversme. The leading organisations of the national resistance movement - the Latvian Central Council, formed in 1943, recognised the validity of the Satversme and the powers of the Latvian parliament, elected in the last free election, - the $4^{\text {th }}$ Convocation of the Saeima - to lead the country until the election of the $5^{\text {th }}$ Convocation of the Saeima in election that would comply with the Satversme. The highest officials of the $4^{\text {th }}$ Convocation of the Saeima became involved in the leadership of the Latvian Central Council - Pauls Kalninš, the Speaker of the Saeima, as well as the ViceSpeakers Kārlis Pauḷks and Jāzeps Rancāns. ${ }^{19}$ On 8 September 1944, the Latvian Central Council adopted the Declaration on the Restoration of the State of Latvia, with Pauls Kalniňs, as the highest official of the state, on the basis of the Satversme, assuming the role of the acting president of the state.$^{20}$ Although the attempts to restore the independence of the state did not lead to immediate success, the Latvian Central Council continued its activities in exile and attempted to form the government in exile. ${ }^{21}$ Following the death of P. Kalniņš and K. Pauluks, the Latvian Central Council established, on 26 April 1947, that, pursuant to the Satversme, the powers of the President of the State and the Speaker of the Saeima had been transferred to J. Rancāns. ${ }^{22}$ Upon J. Rancāns' request, the judges of the supreme

18 Judgement of the Constitutional Court of the Republic of Latvia in the case No. 2007-100102, para. 29.2. Available: https://www.satv.tiesa.gov.lv/web/viewer.html?file=/wp-content/ uploads/2007/04/2007-10-0102_Spriedums_ENG.pdf [last viewed 10.03.2021].

19 Jundzis, T., Turčinskis, Z. Resistance to the Soviet and Nazi Regimes in Latvia, 1940-1985. In: Latvia and Latvians. Collection of scholarly articles in 2 volumes. Vol. II. Riga: Latvian Academy of Science, 2018, pp. 720-722.

20 Pleps, J. Role of the Latvian Central Council's Practice in Interpretation of the Constitution of Latvia. Journal of the University of Latvia. Law, No. 9, 2016, pp. 129-131.

21 Deksnis, E. B. Latvian Exile Government Proposals. Journal of the University of Latvia. Law, No. 9, 2016, pp. 84-85.

22 Pleps, J. Role ..., pp. 130-132. 
court of Latvia - the Latvian Senate - provided their opinion, in which they established the continuous existence of the Latvian state de iure and the validity of the Satversme even in the conditions of occupation. ${ }^{23}$ In these conditions, the Satversme turned into a political symbol of the lost independence and the legal grounds for demanding restoration of an independent state.

\subsection{Reinstatement of Satversme and Restoration of Constitutional Bodies Defined Therein}

The leading political force in regaining Latvia's independence - the Popular Front of Latvia - included in its political programme the restoration of Latvia's independence on the basis of the state continuity. ${ }^{24}$ In the Supreme Council's election, those supporting regaining of Latvia's independence gained the needed majority of votes, and, on 4 May 1990, the Supreme Council adopted the declaration "On the Restoration of Independence of the Republic of Latvia". ${ }^{25}$ Para. 3 of the Declaration reinstated Satversme on the territory of Latvia; however, at the same time, para. 4 and para. 7 of the Declaration envisaged recasting of the Satversme. Pursuant to para. 4 of the Declaration, Articles 1, 2, 3 and 6 of the Satversme, which define the constitutionally legal basis of the Latvian state, remained in force.

The conviction regarding the possibility and even necessity to reinstate Satversme in full consolidated, and the idea of drafting a new constitution was abandoned. ${ }^{26}$ Article 1 of the constitutional law of 21 August 1991 "On the Statehood of the Republic of Latvia" 27 declared that the Satversme defined the statehood of the Republic of Latvia. On 6 July 1993, when the $5^{\text {th }}$ Convocation of the Saeima, elected in accordance with the Satversme, convened for its first sitting, the Satversme was reinstated in full de facto. ${ }^{28}$ Reinstatement of the Satversme is a relatively rare occasion, marking an occasion when a constitution has been successfully reinstated in the legal and social reality following an interruption of almost half a century. It also consolidates and confirms the continuity of the Latvian state. ${ }^{29}$

The reinstatement of the Satversme meant also reinstating the constitutional bodies referred to therein. After the reinstatement of the Satversme, all constitutional bodies envisaged in the Satversme and the laws regulating their operation were reestablished. It is worth emphasising that these laws predominantly were restored very close to their wording in the period until Latvia's occupation. In several cases, even the titles of the adopted laws pointed to this. ${ }^{30}$

23 Senatoru atzinums [Advisory Opinion of the Senatores]. Latvju Zinas, No. 29, 17.04.1948, pp. 1-2.

24 Jundzis, T. Regaining the Independence of Latvia. In: Latvia and Latvians. Collection of scholarly articles in 2 volumes. Vol. I. Rīga: Latvian Academy of Science, 2018, pp. 79-80.

25 Augstākās padomes deklarācija "Par Latvijas Republikas neatkarības atjaunošanu” [Declaration of the Supreme Council “On the Restoration of Independence of the Republic of Latvia”] (04.05.1990). Available: https://likumi.lv/ta/id/75539-par-latvijas-republikas-neatkaribas-atjaunosanu [last viewed 10.03.2021].

26 Ziemele, I. State Continuity and Nationality: The Baltic States and Russia: Past, Present and Future as Defined by International Law. Leiden: Martinus Nijhoff Publishers, 2005, pp. 32-35.

27 Konstitucionālais likums "Par Latvijas Republikas valstisko statusu" [Constitutional Law "On the Statehood of the Republic of Latvia"] (21.08.1991). Available: https://likumi.lv/ta/id/69512-parlatvijas-republikas-valstisko-statusu [last viewed 10.03.2021].

28 Latvijas Republikas 5. Saeimas pirmās sēdes 1993. gada 6. jūlijā stenogramma [Transcript of the first sitting of the $5^{\text {th }}$ Convocation of the Saeima of the Republic of Latvia on 6 July 1993]. Available: https://www.saeima.lv/steno/st_93/060793.html [last viewed 10.03.2021].

29 Ziemele, I. State Continuity ..., pp. 35-36.

30 Kusiņš, G., Pleps, J. Valsts iekārtas un tiesību sistēmas atjaunošana [Restoration of the Constitutional Order and the Legal System]. In: Latvijas valsts tiesību avoti. Valsts dibināšana - neatkarības atjaunošana 
On 20 October 1992, the Supreme Council also adopted a law on holding the election of the $5^{\text {th }}$ Convocation of the Saeima in accordance with the Satversme. The law of the Supreme Council of 20 October 1992 "On the Election of the $5^{\text {th }}$ Saeima" 1 , with some derogations, actually took over in full the regulation of the "Law on Elections of the Saeima" of 9 June 1922. It is also relevant that the Supreme Council confirmed the continuity of legislators in the Republic of Latvia by announcing the election of the $5^{\text {th }}$ Saeima it continued the numbering of the parliament, commenced before Latvia's occupation. ${ }^{32}$ With the election of the $5^{\text {th }}$ Convocation of the Saeima in accordance with Article 12 and Article 13 of the Satversme, the powers of the $4^{\text {th }}$ Saeima legally expired. J. Rancāns, as the acting Speaker of the Saeima in conditions of occupation, is officially included in the gallery of the Saeima's Speakers. ${ }^{33}$

Upon commencing its work, the $5^{\text {th }}$ Convocation of Saeima decided at its first sitting to apply to its work the Rules of Procedure of the Saeima of 1929, until new Rules of Procedure of the Saeima would be drafted. This decision by the Saeima attested not only to the symbolic or technical reinstatement of old laws but also to the returning of the practice of applying laws, parliamentary traditions and doctrine into the legal reality. The first election of the president following the reinstatement of the Satversme also was held in compliance with the parliamentary customs that had developed before Latvia's occupation. The first election of the president following the full reinstatement of the Satversme marked symbolic continuity of the state, since the newly elected President Guntis Ulmanis was a close relative of the last head of the state before the Republic of Latvia was occupied - the acting President Prime Minister Kārlis Ulmanis. Similarly to the Speaker of the Saeima, the Acting Presidents during the occupation - P. Kalniņš and J. Rancāns - are included on the list of the presidents of the state. ${ }^{34}$

Chapter VI of the Satversme $e^{35}$ "Courts" regained validity in full and unamended. ${ }^{36}$ Thus, the continuity of the basic principles for the functioning of the judicial power was ensured. ${ }^{37}$ On 15 December 1992, the Supreme Court adopted the law "On

[Legal Sources of the Latvian State. Foundation of the State - Restoration of Independence]. Riga: Tiesu namu aǵentūra, 2015, p. 238.

31 Likums "Par 5. Saeimas vēlēšanām" [Law "On the Elections of the $5^{\text {th }}$ Saeima]. Available: https:// likumi.lv/ta/id/66524-par-5-saeimas-velesanam [last viewed 10.03.2021].

32 Kusinšs, G. Latvijas parlamentārisma apskats [A Survey of the Latvian Parliamentarism]. Rīga: Latvijas Republikas Saeima, 2016, p. 57.

33 Ināra Mūrniece: godinām Jāzepu Rancānu par Latvijas valstiskuma stiprināšanu mūža garumā [Ināra Mūrniece: We pay homage to Jāzeps Rancāns for lifelong strengthening of Latvia’s statehood] (21.08.2018). Available: https://www.saeima.lv/lv/par-saeimu/saeimas-darbs/12-saeimas-priekssedetajainara-murniece/12-saeimas-priekssedetajas-aktualitates/27113-inara-murniece-godinam-jazepu-rancanu-par-latvijas-valstiskuma-stiprinasanu-muza-garuma [last viewed 10.03.2021].

34 Address by H. E. President of Latvia Mr Egils Levits Assuming the Office at the Saeima (08.07.2019). Available: https://www.president.lv/en/news/news/address-by-h-e-president-of-latvia-mr-egilslevits-assuming-the-office-at-the-saeima-25796 [last viewed 10.03.2021].

35 Latvijas Republikas Satversme [The Constitution of the Republic of Latvia] (15.02.1922). Available: https://likumi.lv/ta/en/en/id/57980-the-constitution-of-the-republic-of-latvia [last viewed 03.03.2021].

36 See more: Lazdinšs, J. Clashes of Opinion at the Time of Drafting the Satversme of the Republic of Latvia. Journal of the University of Latvia. Law, No. 10, 2017, pp. 98-100. Available: https:// www.journaloftheuniversityoflatvialaw.lu.lv/fileadmin/user_upload/lu_portal/projekti/ journaloftheuniversityoflatvialaw/No10/J.Lazdins.pdf) [last viewed 03.03.2021].

37 "Judges shall be independent and subject only to the law" (Art. 83 of the Satversme) and "Judicial appointments shall be confirmed by the Saeima and they shall be irrevocable" (Art. 84 of the Satversme). 
Judicial Power" ${ }^{38}$ In many respects, the court system was restored as it had been until the Soviet occupation, in compliance with Provisional Statute on the Courts of Latvia and Procedure of Litigations of 6 December 1918. ${ }^{39}$ The continuity of the legal thought is proven, in particular, by the case law of the Latvian courts, inter alia, also by the Constitutional Court's references to the case law of the Senate which had evolved before Latvia's occupation. ${ }^{40}$ The use of the Senate's case law was made possible by the reinstatement of a large number of pre-occupation laws. ${ }^{41}$ The central place among them is occupied by the reinstatement, in 1992-1993, of the Latvian Civil Law, adopted on 28 January $1937^{42}$.

The use of the Senate's case law for the purposes of the further development of the case law in Latvia attests to the continuity of the legal system. ${ }^{43}$ Likewise, it must be highlighted that, following Latvia's occupation, the Senate's Senators in exile, upon the request by the Vice-Speaker of the Saeima Jāzeps Rancāns, prepared a special legal opinion on Latvia's legal status and the validity of the Satversme following the Soviet occupation. ${ }^{44}$

\subsection{Restitution of the Right to Property}

In a democratic state governed by the rule of law, the right to property is a protected value..$^{45}$ Following full restoration of the sovereign state power de facto (1990-1991), elimination of injustices inflicted by the Soviet regime, inter alia, also with respect to the right to property, turned into one of the obligations of the State of Latvia. This also meant denationalisation of properties that had been nationalised by communists. ${ }^{46}$

38 Par tiesu varu [On Judicial Power] (15.12.1992). Available: https://likumi.lv/ta/en/en/id/62847-onjudicial-power [last viewed 03.03.2021].

39 Pagaidu nolikums par Latvijas tiesām un tiesāšanas kārtību [Provisional Statute on the Courts of Latvia and Procedure of Litigations] (06.12.1918). Pagaidu Valdïbas Vēstnesis, No. 1, 14. (01.)12.1918. See more: Nepārtrauktības doktrīna ... [The Continuity Doctrine ...], pp. 345-359.

40 See, for instance: Judgment in the case No. 2007-10-0102, Riga, 29 November 2007. In: Selected Case-Law of the Constitutional Court of the Republic of Latvia: 1996-2017. Riga: The Constitutional Court of the Republic of Latvia, 2018, pp. 271, 282. Available: http://www.satv.tiesa.gov.lv/other/2018ST-Zelta-gala\%20versija.pdf [last viewed 03.03.2021]; Augstākās tiesas Civillietu departamenta (paplašinātā sastāvā) 2005. gada 7. decembra spriedums lietā Nr. SKC-542/2005 [Judgment of the Department of Civil Cases of the Supreme Court (in extended composition) of 7 December 2005 in case No. SKC-542/2005]. Available:

http://www.at.gov.lv/lv/judikatura/judikaturas-nolemumu-arhivs/civillietu-departaments/ hronologiska-seciba?year=2005 [last viewed 03.03.2021]; Augstākās tiesas Administratīvo lietu departamenta 2008. gada 16. oktobra spriedums lietā Nr. SKA-404/2008 [Judgment of the Department of Administrative Cases of the Supreme Court of $16^{\text {th }}$ October 2008 in case No. SKA-404/2008], point 10. Available: https://manas.tiesas.lv/eTiesasMvc/lv/nolemumi. [last viewed 03.03.2021].

${ }^{41}$ Lazdinss, J. Tendencies in the Development of Laws in the Republic of Latvia after the Renewal of Independence in 1990-1991. Journal of the University of Latvia. Law, No. 8, 2015, pp. 47-67. Available: https://www.journaloftheuniversityoflatvialaw.lu.lv/fileadmin/user_upload/lu_portal/projekti/ journaloftheuniversityoflatvialaw/No8/3.Janis_Lazdins.pdf) [last viewed 03.03.2021].

42 Latvijas Civillikums [The Civil Law] (28.01.1937). Available: https://likumi.lv/ta/en/en/id/225418the-civil-law [last viewed 03.03.2021].

43 Lèbers, D. A. Latvijas Senāts viṇdienās un mūsdienās [The Latvian Senate in the Olden and the Current Times]. Latvijas Vēstnesis, No. 387, 29.12.1998, p. 4.

44 Senatoru atzinums [Advisory Opinion of the Senatores]. Latvju Zinas, No. 29, 17.04.1948, pp. 1-2.

45 Pursuant to Article 1 of the Satversme, Latvia is a democratic republic.

46 See Par agrāro reformu Latvijas Republikā [On Agrarian Reform in the Republic of Latvia] (13.06.1990). Available: https://likumi.lv/ta/id/76206-par-agraro-reformu-latvijas-republika [last viewed 03.03.2021]; Par valsts īpašuma un tā konversijas pamatprincipiem [On the basic principles 
There was a considerable variety of the objects of property that had been subjected to denationalisation. To ensure property reform, they were conditionally divided into six groups: 1) land property in rural areas; ${ }^{47}$ 2) land property in cities; ${ }^{48}$ 3) homeownership; ${ }^{49} 4$ ) undertakings; ${ }^{50}$ ) property of religious organisations, ${ }^{51}$ and 6) property of academic lifelong organisations. ${ }^{52}$

Not all objects of property were included in the aforementioned six groups. Therefore, denationalisation of property was implemented also on the basis of a special law. For instance, the right to property was reinstated in this way to the Association of Latvian Estonians ${ }^{53}$, the Association of the Jewish Hospital "Bikur Holim" 54 , etc.

Denationalisation of property in Latvia was aimed at restitution of the right to immovable property. ${ }^{55}$ Restitution of the right to movable property was viewed more as an exception to the general procedure, while the value of nationalised deposits was not compensated at all. Hence, restitution of the right to property in Latvia was not comprehensive. Likewise, it was not always possible to carry out the restitution of the right to immovable property in natura. For example, personal (family) homes, lawfully purchased during the years of Soviet occupation, remained the property of buyers as bona fide acquirers. Likewise, the land on which public roads, national

of the state property and its conversion] (20.03.1991). Available: https://likumi.lv/doc.php?id=65829 [last viewed 03.03.2021].

47 Par zemes reformu Latvijas Republikas lauku apvidos [On Land Reform in Rural Areas of the Republic of Latvia] (21.11.1990). Available: https:/likumi.lv/ta/en/en/id/72849-law-on-land-reformin-the-rural-areas-of-the-republic-of-latvia [last viewed 03.03.2021]; Par zemes privatizāciju lauku apvidos [On Land Privatisation in Rural Areas] (09.07.1992). Available: https://likumi.lv/ta/en/en/ id/74241-on-land-privatisation-in-rural-areas [last viewed 03.03.2021].

48 Par zemes reformu Latvijas Republikas pilsētās [On Land Reform in the Cities of the Republic of Latvia] (20.11.1991). Available: https://likumi.lv/ta/id/70467-par-zemes-reformu-latvijas-republikaspilsetas [last viewed 03.03.2021].

49 Par namīpašumu atdošanu likumīgajiem ippašniekiem [On Returning Homeownerships to their Legal Owners] (30.10.1991). Available: https://likumi.lv/ta/id/70828-par-namipasumu-atdosanulikumigajiem-ipasniekiem [last viewed 03.03.2021]; Par namīpašumu denacionalizāciju Latvijas Republikā [On Denationalisation of Homeownership in the Republic of Latvia] (30.10.1991). Available: https://likumi.lv/ta/id/70829-par-namipasumu-denacionalizaciju-latvijas-republika [last viewed 03.03.2021].

50 Par īpašuma tiesību atjaunošanu uz uzṇēmumiem un citiem īpašuma objektiem [On Renewal of Property Rights to Undertakings and Other Property Objects] (30.03.1993). Available: https://likumi. $\mathrm{lv} / \mathrm{ta} / \mathrm{en} / \mathrm{en} / \mathrm{id} / 60054$-on-renewal-of-property-rights-to-undertakings-and-other-property-objects [last viewed 03.03.2021].

51 Par īpašumu atdošanu reliǵiskajām organizācijām [On Returning Property to Religious Organisations] (12.05.1992). Available: https://likumi.lv/ta/id/65537-par-ipasumu-atdosanu-religiskajamorganizacijam [last viewed 03.03.2021].

52 Par nekustamo īpašumu atdošanu akadēmiskajām mūža organizācijām [On Returning Immovable Property to Academic Lifelong Organisations] (28.11.1996). Available: https://likumi.lv/ta/id/41487par-nekustamo-ipasumu-atdosanu-akademiskajam-muza-organizacijam [last viewed 03.03.2021].

53 Par īpašuma tiesibu atjaunošanu Latvijas Igauṇu biedribai [On Restituting the Title to Property to the Association of Latvian Estonians] (16.01.1997). Available: https://likumi.lv/ta/id/42064-par-ipasumatiesibu-atjaunosanu-latvijas-igaunu-biedribai [last viewed 03.03.2021].

54 Par īpašuma tiesību atjaunošanu Ebreju slimnīcas "Bikur Holim" biedrïbai [On Restituting the Title to Property of the Association of the Jewish Hospital "Bikur Holim"] (21.05.1998). Available: https:// likumi.lv/ta/id/48410-par-ipasuma-tiesibu-atjaunosanu-ebreju-slimnicas-bikur-holim-biedribai [last viewed 03.03.2021].

55 Lazdiņš, J. İpašuma denacionalizācija Latvijas Republikā [Denationalisation of Property in the Republic of Latvia]. In: Nepārtrauktïbas doktrīna ... [The Continuity Doctrine ...], pp. 362-363. 
sports facilities, etc. were located, was not denationalised. ${ }^{56}$ In such cases, former owners and their heirs had the right to be allocated equivalent property, to receive compensation in cash or privatisation certificates in compliance with the procedure set out in law. ${ }^{57}$

At the time when the reform was implemented, extensive public discussions ensued regarding the framework of denationalisation and state's obligations in relation to it. The Constitutional Court of the Republic of Latvia provided an answer to this question:

The State of Latvia is not responsible for the human rights violations, including nationalisation of property, which were committed by the occupation power in the period lasting half a century. The Republic of Latvia does not have the possibilities and neither is it obliged to compensate in full for all damages caused to persons as the result of actions taken by the occupation power. ${ }^{58}$ [The legislator] had the obligation to take measures to redress, to the extent possible, [..] the damages caused by the former regime and to restore justice ${ }^{59}$.

Latvia has completed restitution of the right to property to the extent possible for the state at a given time. Of course, a significant number of errors was made within the framework of this reform. Thus, the conversion process of the state property was unnecessarily hasty. For example, natural persons were given less than four months to apply for the recovery of the objects of property owned by undertakings, hotels, cinemas, pharmacies, hospitals, etc. (land and home ownership was an exception, regulated by other laws). ${ }^{60}$ Another problem was caused by expanding the circle of heirs during the period of restitution of property rights. At the time when land reform was commenced in rural areas, the Civil Code of the Latvian Soviet Socialist Republic $(27.12 .1963)^{61}$ was in effect. Pursuant to the Civil Code, the closest relatives were

56 See more Lazdiņš, J. Zemes īpašuma nacionalizācijas un denacionalizācijas pieredze Latvijā (19.-21. gadsimts) [The Experience of Nationalising and Denationalising Land Property in Latvia (19 $9^{\text {th }}-20^{\text {th }}$ century]. Likums un Tiesības, Vol. 7, No. 6, 2005, pp. 168-178; Grūtups, A., Krastiņš, E. İpašuma reforma Latvijā [Property Reform in Latvia]. Rīga: Mans īpašums, 1995.

57 Par zemes privatizāciju lauku apvidos [On Land Privatisation in Rural Areas], Art. 4 (3), 12-14; Par zemes reformu Latvijas Republikas pilsētās [On Land Reform in the Cities of the Republic of Latvia], Art. 14; Par privatizācijas sertifikātiem [On Privatisation Certificates] (16.03.1995.). Available: https:// likumi.lv/ta/id/34503-par-privatizacijas-sertifikatiem [last viewed 03.03.2021] and other regulatory enactments [last viewed 03.03.2021].

58 Latvijas Republikas Satversmes tiesas 2003. gada 25. marta spriedums lietā Nr. 2002-12-01 [Judgement of the Constitutional Court of the Republic of Latvia of 25 March 2003 in case No. 2002-12-01], para. 1 of the Findings. Available: https://likumi.lv/doc.php?id=73143 [last viewed 03.03.2021].

59 Latvijas Republikas Satversmes tiesas 2011. gada 28. novembra spriedums lietā Nr. 201102-01 [Judgement of the Constitutional Court of the Republic of Latvia of 28 November 2011 in case No. 2011-02-01], para. 8.1. Available: http://www.satv.tiesa.gov.lv/wp-content/ uploads/2016/02/2011-02-01_Spriedums.pdf [last viewed 03.03.2021].

60 Par pieteikumu pieņemšanu no nacionalizēto un citādi nelikumīgi atṇemto nekustamo īpašumu (uzñēmumu un citu īpašuma objektu) īpašniekiem - fiziskajām personām [On Accepting Applications from Owners - Natural Persons - of Nationalised or Otherwise Unlawfully Divested Immovable Property (undertakings and other objects of property)] (31.03.1992). Available: https://likumi.lv/ta/ id/65486-par-pieteikumu-pienemsanu-no-nacionalizeto-un-citadi-nelikumigi-atnemto-nekustamoipasumu-uznemumu-un-citu-ipasuma-objektu [last viewed 03.03.2021].

61 Latvijas Padomju Sociālistiskās Republikas Civilkodekss [The Civil Code of the Latvian Soviet Socialist Republic] (27.12.1963). Latvijas Padomju Sociālistiskās Republikas Augstākās Padomes un Valdības Ziṇotājs, No. 1, 09.01.1964. 
invited to inherit property. ${ }^{62}$ On 1 September 1992, general clauses, rights in rem and inheritance rights contained in the 1937 Latvian Civil Law were reinstated. ${ }^{63}$

The Civil Law, drawn up in the Romano-Germanic legal tradition, did not limit the circle of heirs to close relatives. Consequently, after the Civil Law entered into effect, a considerable number of persons, who pursuant to the Civil Code were not recognised as heirs, became entitled to request restitution of the title to property. However, before the more distant relatives, in accordance with the circle of relatives expanded by the Civil Law, could apply for the restitution of the title to property, the land could have been transferred into permanent use to another person in the general procedure for privatising state property. In such a case, the former owners had to accept allocation of an equivalent land plot or compensation.

The emergence of the so-called divided property rights takes a special place in the "list of problems" of property reform. It originated in restoring the right of property to land on which multiapartment residential buildings had been erected. The divided immovable property right was legalised by the Supreme Council of the Republic of Latvia on 7 July 1992 by adopting the law "On the Time of Entry into Force and Procedure of Application of the Introductory Part, Parts on Inheritance Law and Property Law of the Renewed Civil Law of the Republic of Latvia of 1937". ${ }^{64}$ The purpose of the law to legalise the existing property relations was reached but this could not be said about the future relationships between owners.

Setting the amount of land lease has turned into "the apple of discord" for landowners and owners of multiapartment residential buildings. Following several judgements by the Constitutional Court, the legislator's attempts to resolve this problem by setting the ceiling for the land lease have failed. Currently, the amount of land lease is set by the parties, agreeing in writing. ${ }^{65}$ To date, the legislator has not succeeded in adopting legal regulations on how the owners of apartments in multiapartment residential buildings could purchase land from landowners, nor in enforcing the findings included in the Constitutional Court's case law:

The legislator is the one who, abiding by the case law of the Constitutional Court in matters of compulsory lease, must find such a solution to a particular situation in a procedure within which possible restrictions of persons' fundamental rights are duly assessed and where the rights of landowners and the owners of multiapartment buildings are justly balanced. ${ }^{66}$

62 "Firstly - children of the deceased (also, adopted children), the spouse and parents (also, adoptive), as well as the deceased person's child born after his death; the second line - siblings of the deceased, his grandfather and grandmother from both his father's and mother's side of the family. [..] Grandchildren and great-grandchildren of the leaver of the estate are lawful heirs if, at the opening of the succession, the parent, who himself would have been the heir, is not alive." (Art. 555).

63 Par atjaunotā Latvijas Republikas 1937.gada Civillikuma ievada, mantojuma tiesību un lietu tiesību daḷas spēkā stāšanās laiku un piemērošanas kārtību [On the Time of Entry into Force and Procedure of Application of the Introductory Part, Parts on Inheritance Law and Property Law of the Renewed Civil Law of the Republic of Latvia of 1937] (07.07.1992). Available: https://likumi.lv/ta/id/75530par-atjaunota-latvijas-republikas-1937gada-civillikuma-ievada-mantojuma-tiesibu-un-lietu-tiesibudalas-speka-stasanas-laiku-un-piemerosanas-kartibu [last viewed 03.03.2021].

64 Ibid., Art. 14.

65 See Par zemes reformu Latvijas Republikas pilsētās [On Land Reform in the Cities of the Republic of Latvia], Art. $12\left(2^{1}\right)$; Par valsts un pašvaldību dzīvojamo māju privatizāciju [On Privatisation of State and Local Government Residential Homes] (21.06.1995), Art. 54 (2). Available: https://likumi.lv/ta/ id/35770-par-valsts-un-pasvaldibu-dzivojamo-maju-privatizaciju [last viewed 03.03.2021].

66 Latvijas Republikas Satversmes tiesas 2018. gada 12. aprịḷa spriedums lietā Nr. 2017-17-01 [Judgement of the Constitutional Court of the Republic of Latvia of 12 April 2018 No. 2017-17-01], para. 24. 
No major property reform proceeds without errors and valid criticism. In this respect, Latvia is no exception. However, the conversion of state property into private property, even with all its deficiencies, has significantly reinforced the foundations of Latvia as a democratic state governed by the rule of law ensuring (substantially) the continuity of the right to property of former owners and their heirs. Therefore, denationalisation of property should be viewed as an important aspect in substantiating the continuity of the State of Latvia ${ }^{67}$, also symbolising restitution of the sovereign power of Latvia as a state governed by the rule of law in full in the area of property rights.

\section{Summary}

1. Since its proclamation on 18 November 1918, the Republic of Latvia has continuously existed de iure as an internationally recognised subject of international law. The Republic of Latvia continued to implement the functions of state even during occupation. Throughout the entire period of occupation, the diplomatic and consular services of the Republic of Latvia operated continuously, representing the interests of the Republic of Latvia abroad and expressing its official position.

2. During the entire period of occupation, the Satversme continued to be valid as the only constitution of the Republic of Latvia, and the perseverance of the national resistance movement was the necessary evidence in the fight for restoration of the independence of the Republic of Latvia. The Central Council of Latvia was organised on the basis of the Satversme as the most significant organisation of the national resistance movement, ensuring the continuity of state power.

3. Pauls Kalninšs, the Speaker of the $4^{\text {th }}$ Saeima, is to be recognised as the legitimate acting President of the State, who undertook these obligations based on the Satversme in the circumstances where the state was unlawfully occupied. Similarly, the Vice-Speaker of the Saeima, Jāzeps Rancāns, is to be considered a legitimate acting President of the state and the Speaker of the Saeima, who, pursuant to the Satversme, assumed these obligations after Pauls Kalniņš̀ demise.

4. Restitution of the right to property to the former owners and their heirs implemented after the collapse of the Soviet power, is an important aspect in substantiating the continuity of the State of Latvia and symbolises a full restitution of the sovereign state power of Latvia as a state governed by the rule of law also in the area of the right to property.

\section{Sources}

\section{Bibliography}

1. Bilmanis, A. Latvia Between the Anvil and the Hammer. Washington: The Latvian Legation, 1945, $64 \mathrm{p}$.

2. Bilmanis, A. Latvia under German Occupation, 1941-1943. Washington: Press bureau of the Latvian Legation, 1943, Vol. I, 114 p.; 1944, Vol. II, 30 p.

3. Bilmanis, A. The Baltic States in Postwar Europe. Washington: Press bureau of the Latvian Legation, $1943,48 \mathrm{p}$.

Available: https://likumi.lv/ta/id/298335-par-2017-gada-1-junija-likuma-grozijumi-likuma-par-valstsun-pasvaldibu-dzivojamo-maju-privatizaciju-1-panta-un-2017-gada-22-ju... [last viewed 03.03.2021].

67 Nepārtrauktỉbas doktrīna ... [The Continuity Doctrine ...], pp. 360-383. 
4. Deksnis, E. B. Latvian Exile Government Proposals. Journal of the University of Latvia. Law, No. 9, 2016. pp. 78-90.

5. Feldmanis, I., Freimanis, A. A., Lerhis, A., Ziemele, I. Latvijas valsts okupācijas gados [The Latvian State in the Years of Occupation]. In: Dokumenti par Latvijas valsts starptautisko atzišanu, neatkarības atjaunošanu un diplomātiskajiem sakariem 1918-1998 [Documents on the International Recognition, Restoration of Independence and Diplomatic Relations of the State of Latvia in 1918-1998]. Rīga: Nordik, 1999, pp. 127-183.

6. Gore, I., Stranga, A. Latvija: neatkarības mijkrēslis. Okupācija. 1939. gada septembris - 1940. gada jūlijs [Latvia: The Twilight of Independence. Occupation. September 1939 - July 1940]. Rìga: Izglītiba, 1992, pp. 115-117.

7. Grūtups, A., Krastiņš, E. İpašuma reforma Latvijā [Property Reform in Latvia]. Riga: Mans ipašums, 1995.

8. Jundzis, T. Regaining the Independence of Latvia. In: Latvia and Latvians. Collection of scholarly articles in 2 volumes. Vol. I. Rīga: Latvian Academy of Science, 2018, pp. 54-92.

9. Jundzis, T., Turčinskis, Z. Resistance to the Soviet and Nazi Regimes in Latvia, 1940-1985. In: Latvia and Latvians. Collection of scholarly articles in 2 volumes. Vol. II. Rīga: Latvian Academy of Science, 2018, pp. 710-750.

10. Kangeris, K. Latvijas pavalstnieki kara laika Eiropā [Latvian Subjects during the War in Europe]. Mājas Viesis, 19.04.2003, pp. 8-9.

11. Kusiņš, G. Latvijas parlamentārisma apskats [A Survey of the Latvian Parliamentarism]. Riga: Latvijas Republikas Saeima, 2016.

12. Kusiņš, G., Pleps, J. Valsts iekārtas un tiesību sistēmas atjaunošana [Restoration of the Constitutional Order and the Legal System]. In: Latvijas valsts tiesību avoti. Valsts dibināšana neatkarības atjaunošana [Legal Sources of the Latvian State. Foundation of the State - Restoration of Independence]. Rīga: Tiesu namu aǵentūra, 2015, pp. 234-298.

13. Latvijas Republikas oficiālā nostāja Latvijas diplomātiskā dienesta dokumentos 1940.-1991. gadā. Dokumentu krājums [The Official Position of the Republic of Latvia in the Documents of the Latvian Diplomatic Service in 1940-1991. Collection of Documents]. Compiled by Lerhis, A. Rīga: Latvijas vēstures institūta apgāds, 2015.

14. Lazdinšs, J. Clashes of Opinion at the Time of Drafting the Satversme of the Republic of Latvia. Journal of the University of Latvia. Law, No. 10, 2017, pp. 93-103. Available: https:// www.journaloftheuniversityoflatvialaw.lu.lv/fileadmin/user_upload/lu_portal/projekti/ journaloftheuniversityoflatvialaw/No10/J.Lazdins.pdf [last viewed 03.03.2021].

15. Lazdiņš, J. İpašuma denacionalizācija Latvijas Republikā [Denationalisation of Property in the Republic of Latvia]. In: Nepārtrauktības doktrīna Latvijas vēstures kontekstā [The Continuity Doctrine in the Context of Latvia's History]. Collective of authors, research supervisor Jundzis, T. Rīga: Latvijas Zinātņu akadēmijas Baltijas stratēgisko pētījumu centrs, 2017, pp. 360-383.

16. Lazdiņš, J. Tendencies in the Development of Laws in the Republic of Latvia after the Renewal of Independence in 1990-1991. Journal of the University of Latvia. Law, No. 8, 2015, pp. 43-67. Available: https://www.journaloftheuniversityoflatvialaw.lu.lv/fileadmin/user_upload/lu_portal/ projekti/journaloftheuniversityoflatvialaw/No8/3.Janis_Lazdins.pdf) [last viewed 03.03.2021].

17. Lazdiņš, J. Zemes ìpašuma nacionalizācijas un denacionalizācijas pieredze Latvijā (19.-21. gadsimts) [The Experience of Nationalising and Denationalising Land Property in Latvia $\left(19^{\text {th }}-20^{\text {th }}\right.$ century]. Likums un Tiesības, Vol. 7, No. 6, 2005, pp. 168-178.

18. Lèbers, D. A. Latvijas Senāts viṇdienās un mūsdienās [The Latvian Senate in the Olden and the Current Times]. Latvijas Vēstnesis, No. 387, 29.12.1998, p. 4.

19. [Lerhis, A.]. Ieskats Latvijas Republikas ārlietu dienesta vēsturē (1917-1997). [Insight into the History of the Foreign Service of the Republic of Latvia (1917-1997)]. In: Latvijas ārlietu dienesta rokasgrāmata [Handbook of Foreign Service of Latvia]. Rīga: Latvijas Republikas Ārlietu ministrija, 1997, pp. 10-29.

20. Lerhis, A. Neatkarības idejas saglabāšana pēckara gados: Latvijas diplomātiskā dienesta ieguldījums mūsu valsts de iure statusa saglabāšanā (1940.-1988. g.) [Maintaining the Idea of Independence during the Post-war Years: Contribution of the Latvian Diplomatic Service to Maintaining de iure Status of Our State (1940-1988)]. Diena, 13.02.1998, p. 13.

21. Lerhis, A. Pārmaiṇas Latvijas diplomātiskā dienesta darbībā (1940. g. jūnijs - 1942. g. augusts) [Changes in the Operations of the Latvian Diplomatic Service (June 1940 - August 1942)]. In: Vēsturnieks profesors Dr. phil., LZA ārzemju loceklis Andrievs Ezergailis: Biobibliogrāfija, darbabiedru veltījumi 70 gadu jubilejā [Historian Professor Dr. phil., LAS Foreign Member Andrievs Ezergailis: Biobibliography, Dedications of Colleagues on the $70^{\text {th }}$ Anniversary]. Riga: Latvijas vēstures institūta apgāds, 2000, pp. 164-190. 
22. Lūsis, J. Latvijas diplomātu darbs [Work of Latvian Diplomats]. Daugavas Vanagu Mēnešraksts, No. 3, 1990, pp. 9-14.

23. Nepārtrauktības doktrīna Latvijas vēstures kontekstā [The Continuity Doctrine in the Context of Latvia's History]. Collective of authors, research supervisor Jundzis, T. Rìga: Latvijas Zinātņu akadēmijas Baltijas stratēgisko pētījumu centrs, 2017.

24. Pleps, J. Role of the Latvian Central Council's Practice in Interpretation of the Constitution of Latvia. Journal of the University of Latvia. Law, No. 9, 2016, pp. 126-138

25. Rietumvalstu nostāja Baltijas valstu jautājumā 1940.-1991. gadā: Dokumentu krājums [Position of the Western Countries on the Issue of Baltic States in 1940-1991. Collection of Documents]. Compiled by Lerhis, A. Rīga: Latvijas vēstures institūta apgāds, 2018.

26. Senatoru atzinums [Advisory Opinion of the Senatores]. Latvju Ziņas, No. 29, 17.04.1948, pp. $1-2$.

27. Sūtniecība Vašingtonā [Legation in Washington]. In: Latvju Enciklopēdija [Latvian Encyclopaedia]. Ed. Andersons, E. Vol. 4. Rockville, 1990, pp. 509-512.

28. Ziemele, I. State Continuity and Nationality: The Baltic States and Russia: Past, Present and Future as Defined by International Law. Leiden: Martinus Nijhoff Publishers, 2005.

\section{Normative Acts}

\section{Constitutional Laws}

1. Latvijas Republikas Satversme [The Constitution of the Republic of Latvia] (15.02.1922). Available: https://likumi.lv/ta/en/en/id/57980-the-constitution-of-the-republic-of-latvia [last viewed 03.03.2021].

2. Augstākās padomes deklarācija "Par Latvijas Republikas neatkarības atjaunošanu” [Declaration of the Supreme Council "On the Restoration of Independence of the Republic of Latvia"] (04.05.1990). Available: https://likumi.lv/ta/id/75539-par-latvijas-republikas-neatkaribasatjaunosanu [last viewed 10.03.2021].

3. Konstitucionālais likums "Par Latvijas Republikas valstisko statusu" [Constitutional Law "On the Statehood of the Republic of Latvia”] (21.08.1991). Available: https://likumi.lv/ta/id/69512-parlatvijas-republikas-valstisko-statusu [last viewed 10.03.2021].

\section{Legislation}

1. Pagaidu nolikums par Latvijas tiesām un tiesāšanas kārtību [Provisional Statute on the Courts of Latvia and Procedure of Litigations] (06.12.1918). Pagaidu Valdības Vēstnesis, No. 1, 14.(1.)12.1918.

2. Latvijas Civillikums [The Civil Law] (28.01.1937). Available: https://likumi.lv/ta/en/en/ id/225418-the-civil-law [last viewed 03.03.2021].

3. Latvijas Padomju Sociālistiskās Republikas Civilkodekss [The Civil Code of the Latvian Soviet Socialist Republic] (27.12.1963). Latvijas Padomju Sociālistiskās Republikas Augstākās Padomes un Valdības Ziṇotājs, No. 1, 09.01.1964.

4. Par agrāro reformu Latvijas Republikā [On Agrarian Reform in the Republic of Latvia] (13.06.1990). Available: https://likumi.lv/ta/id/76206-par-agraro-reformu-latvijas-republika [last viewed 03.03.2021].

5. Par zemes reformu Latvijas Republikas lauku apvidos [On Land Reform in Rural Areas of the Republic of Latvia] (21.11.1990). Available: https://likumi.lv/ta/en/en/id/72849-law-on-landreform-in-the-rural-areas-of-the-republic-of-latvia [last viewed 03.03.2021].

6. Par valsts ipašuma un tā konversijas pamatprincipiem [On the basic principles of the state property and its conversion] (20.03.1991). Available: https://likumi.lv/doc.php?id=65829 [last viewed 03.03.2021].

7. Par namīpašumu atdošanu likumīgajiem īpašniekiem [On Returning Homeownerships to their Legal Owners] (30.10.1991). Available: https://likumi.lv/ta/id/70828-par-namipasumuatdosanu-likumigajiem-ipasniekiem [last viewed 03.03.2021].

8. Par namīpašumu denacionalizāciju Latvijas Republikā [On Denationalisation of Homeownership in the Republic of Latvia] (30.10.1991). Available: https://likumi.lv/ta/id/70829-par-namipasumudenacionalizaciju-latvijas-republika [last viewed 03.03.2021].

9. Par zemes reformu Latvijas Republikas pilsētās [On Land Reform in the Cities of the Republic of Latvia] (20.11.1991). Available: https://likumi.lv/ta/id/70467-par-zemes-reformu-latvijasrepublikas-pilsetas [last viewed 03.03.2021].

10. Par pieteikumu pieņemšanu no nacionalizēto un citādi nelikumīgi atņemto nekustamo īpašumu (uzṇēmumu un citu īpašuma objektu) ỉpašniekiem - fiziskajām personām [On Accepting 
Applications from Owners - Natural Persons - of Nationalised or Otherwise Unlawfully Divested Immovable Property (undertakings and other objects of property)] (31.03.1992). Available: https://likumi.lv/ta/id/65486-par-pieteikumu-pienemsanu-no-nacionalizeto-uncitadi-nelikumigi-atnemto-nekustamo-ipasumu-uznemumu-un-citu-ipasuma-objektu [last viewed 03.03.2021].

11. Par ìpašumu atdošanu reliǵiskajām organizācijām [On Returning Property to Religious Organisations] (12.05.1992). Available: https://likumi.lv/ta/id/65537-par-ipasumu-atdosanureligiskajam-organizacijam [last viewed 03.03.2021].

12. Par atjaunotā Latvijas Republikas 1937. gada Civillikuma ievada, mantojuma tiesību un lietu tiesību daḷas spēkā stāšanās laiku un piemērošanas kārtību [On the Time of Entry into Force and Procedure of Application of the Introductory Part, Parts on Inheritance Law and Property Law of the Renewed Civil Law of the Republic of Latvia of 1937 (07.07.1992). Available: https://likumi.lv/ ta/id/75530-par-atjaunota-latvijas-republikas-1937gada-civillikuma-ievada-mantojuma-tiesibuun-lietu-tiesibu-dalas-speka-stasanas-laiku-un-piemerosanas-kartibu [last viewed 03.03.2021].

13. Par zemes privatizāciju lauku apvidos [On Land Privatisation in Rural Areas] (09.07.1992). Available: https://likumi.lv/ta/en/en/id/74241-on-land-privatisation-in-rural-areas [last viewed 03.03.2021].

14. Par tiesu varu [On Judicial Power] (15.12.1992). Available: https://likumi.lv/ta/en/en/id/62847on-judicial-power [last viewed 03.03.2021].

15. Par 5. Saeimas vēlēšanām [On the Elections of the $5^{\text {th }}$ Saeima] (20.10.1992). Available: https:// likumi.lv/ta/id/66524-par-5-saeimas-velesanam [last viewed 10.03.2021].

16. Par ìpašuma tiesību atjaunošanu uz uzṇēmumiem un citiem ìpašuma objektiem [On Renewal of Property Rights to Undertakings and Other Property Objects] (30.03.1993). Available: https://likumi.lv/ta/en/en/id/60054-on-renewal-of-property-rights-to-undertakings-and-otherproperty-objects [last viewed 03.03.2021].

17. Par privatizācijas sertifikātiem [On Privatisation Certificates] (16.03.1995). Available: https:// likumi.lv/ta/id/34503-par-privatizacijas-sertifikatiem [last viewed 03.03.2021].

18. Par valsts un pašvaldību dzīvojamo māju privatizāciju [On Privatisation of State and Local Government Residential Homes] (21.06.1995). Available: https://likumi.lv/ta/id/35770-parvalsts-un-pasvaldibu-dzivojamo-maju-privatizaciju [last viewed 03.03.2021].

19. Par nekustamo īpašumu atdošanu akadēmiskajām mūža organizācijām [On Returning Immovable Property to Academic Lifelong Organisations] (28.11.1996). Available: https://likumi.lv/ta/ id/41487-par-nekustamo-ipasumu-atdosanu-akademiskajam-muza-organizacijam [last viewed 03.03.2021].

20. Par īpašuma tiesību atjaunošanu Latvijas Igauṇu biedrībai [On Restituting the Title to Property to the Association of Latvian Estonians] (16.01.1997). Available: https://likumi.lv/ta/id/42064par-ipasuma-tiesibu-atjaunosanu-latvijas-igaunu-biedribai [last viewed 03.03.2021].

21. Par īpašuma tiesību atjaunošanu Ebreju slimnīcas "Bikur Holim" biedrībai [On Restituting the Title to Property of the Association of the Jewish Hospital "Bikur Holim"] (21.05.1998). Available: https://likumi.lv/ta/id/48410-par-ipasuma-tiesibu-atjaunosanu-ebreju-slimnicas-bikur-holimbiedribai [last viewed 03.03.2021].

\section{Case Law}

1. Latvijas Republikas Satversmes tiesas 2003. gada 25. marta spriedums lietā Nr. 2002-12-01 [Judgement of the Constitutional Court of the Republic of Latvia of 25 March 2003 in case No. 2002-12-01]. Available: https://likumi.lv/doc.php?id=73143 [last viewed 03.03.2021].

2. Judgment in the case No. 2007-10-0102, Riga, 29 November 2007. In: Selected Case-Law of the Constitutional Court of the Republic of Latvia: 1996-2017. Riga: The Constitutional Court of the Republic of Latvia, 2018. Available: http://www.satv.tiesa.gov.lv/other/2018-ST-Zelta-gala\%20 versija.pdf [last viewed 03.03.2021].

3. Latvijas Republikas Satversmes tiesas 2010. gada 13. maija spriedums lietā Nr. 2009-94-01 [Judgement by the Constitutional Court of the Republic of Latvia of 13 May 2010 in Case No. 2009-94-01]. Available: http://www.satv.tiesa.gov.lv/upload/spriedums_2009_94_01.htm [last viewed 12.12.2015].

4. Latvijas Republikas Satversmes tiesas 2011. gada 28. novembra spriedums lietā Nr. 2011-02-01 [Judgement of the Constitutional Court of the Republic of Latvia of 28 November 2011 in case No. 2011-02-01]. Available: http://www.satv.tiesa.gov.lv/wp-content/uploads/2016/02/2011-02-01_ Spriedums.pdf [last viewed 03.03.2021]. 
5. Latvijas Republikas Satversmes tiesas 2018. gada 12. aprīḷa spriedums lietā Nr. 2017-17-01 [Judgement of the Constitutional Court of the Republic of Latvia of 12 April 2018 No. 2017-1701]. Available: https://likumi.lv/ta/id/298335-par-2017-gada-1-junija-likuma-grozijumi-likumapar-valsts-un-pasvaldibu-dzivojamo-maju-privatizaciju-1-panta-un-2017-gada-22-ju... [last viewed 03.03.2021].

6. Augstākās tiesas Civillietu departamenta (paplašinātā sastāvā) 2005. gada 7. decembra spriedums lietā Nr. SKC-542/2005 [Judgment of the Department of Civil Cases of the Supreme Court (in extended composition) of $7^{\text {th }}$ December 2005 in case No. SKC-542/2005]. Available: http://www. at.gov.lv/lv/judikatura/judikaturas-nolemumu-arhivs/civillietu-departaments/hronologiskaseciba? year=2005 [last viewed 03.03.2021].

7. Augstākās tiesas Administratīvo lietu departamenta 2008. gada 16. oktobra spriedums lietā Nr. SKA-404/2008 [Judgment of the Department of Administrative Cases of the Supreme Court of $16^{\text {th }}$ October 2008 in case No. SKA-404/2008]. Available: https://manas.tiesas.lv/eTiesasMvc/ lv/nolemumi [last viewed 03.03.2021].

\section{Archival Documents}

1. A. Bīlmanis' letter of 07.09.1940 to K. Zariņš; file “1940. D. 125.63/ Latvian Consulate-General, New York”. Latvian National Archives, Latvian State Historical Archive, Latvian Legation London fund.

2. File "Miscellaneous (War time), mainly Washington". Latvian National Archives, Latvian State Historical Archive, Latvian Legation London fund.

3. File "Sarakste ar Foreign Office lìdz 1945. g." [Correspondence with Foreign Office until 1945]. LNA LSHA, Latvian Legation London fund, box No. 460.

4. Hoover Institution Archives, Vilis Sumans collection, box 1, folder "Increment April 1978".

5. Latvian National Archives, Latvian State Historical Archive, fund 293, description 1, file 4388, pp. $12,16,17,28$.

\section{Published Documents}

1. Statement of Acting Secretary of State Sumner Welles, July 23, 1940. In: U.S. Department of State, Department of State Bulletin III. Washington, U.S. Government Printing Office, July 27, 1940. Vol. III, No. 57, p. 48.

\section{Other Sources}

1. Latvijas Republikas 5. Saeimas pirmās sēdes 1993. gada 6. jūlijā stenogramma [Transcript of the first sitting of the $5^{\text {th }}$ Convocation of the Saeima of the Republic of Latvia on 6 July 1993]. Available: https://www.saeima.lv/steno/st_93/060793.html [last viewed 10.03.2021].

2. Ināra Mūrniece: godinām Jāzepu Rancānu par Latvijas valstiskuma stiprināšanu mūža garumā [Ināra Mūrniece: We pay homage to Jāzeps Rancāns for lifelong strengthening of Latvia's statehood] (21.08.2018). Available: https://www.saeima.lv/lv/par-saeimu/saeimas-darbs/12saeimas-priekssedetaja-inara-murniece/12-saeimas-priekssedetajas-aktualitates/27113-inaramurniece-godinam-jazepu-rancanu-par-latvijas-valstiskuma-stiprinasanu-muza-garuma [last viewed 10.03.2021].

3. Address by H. E. President of Latvia Mr Egils Levits Assuming the Office at the Saeima (08.07.2019). Available: https://www.president.lv/en/news/news/address-by-h-e-president-oflatvia-mr-egils-levits-assuming-the-office-at-the-saeima-25796 [last viewed 10.03.2021].

4. Address of President of Latvia, Egils Levits, at the reception marking 100 years of foreign service (09.09.2019). Available: https://www.president.lv/en/news/news/address-of-president-of-latviaegils-levits-at-the-reception-marking-100-years-of-foreign-service-25901\#gsc.tab=0 [last viewed 02.04.2021]. 